\title{
Faithful Rulers and Theological Deviance: Ephrem the Syrian and Jacob of Serugh on the Roman Emperor
}

The involvement of Roman Emperors in theological controversies brought both praise and resentment. The sudden entry of Constantine I (r. 306-337) and his successors into ecclesiastical affairs inspired starkly different responses. ${ }^{1}$ The efforts of Emperor Justinian I (r. 527-565) and Empress Theodora (c. 497-548) to reconcile pro- and anti-Chalcedonian parties proved similarly divisive. ${ }^{2}$ The complex development of Christian political thought in late antiquity has become a major area of scholarly interest, ${ }^{3}$ and the perspectives of Syriac authors on this topic have recently

In addition to the feedback I received at the conference, I am grateful to Blake Hartung, Alexandra Hasse-Ungeheuer, and Hartmut Leppin for their comments and suggestions on various versions of this essay.

1 For example, Michael Gaddis, There Is No Crime for Those Who Have Christ: Religious Violence in the Christian Roman Empire, Transformation of the Classical Heritage 39 (Berkeley 2005), 78, argues that support for an imperial role in the church was largely found among the opponents of Nicene theology until the last quarter of the fourth century. Studies on church and state during Constantine's reign are legion. See, for example, the following recent studies: Harold A. Drake, Constantine and the Bishops: The Politics of Intolerance, Ancient Society and History (Baltimore 2000); Harold A. Drake, "The Impact of Constantine on Christianity," in The Cambridge Companion to the Age of Constantine, ed. Noel Emmanuel Lenski, Cambridge Companions to Literature and Classics (Cambridge 2006), 111-136; Mark Edwards, "The Beginnings of Christianization," in The Cambridge Companion to the Age of Constantine, ed. Noel Emmanuel Lenski, Cambridge Companions to Literature and Classics (Cambridge 2006), 137-158; Klaus W. Rosen, Konstantin der Große: Kaiser zwischen Machtpolitik und Religion (Stuttgart 2013); A. Edward Siecienski, ed., Constantine: Religious Faith and Imperial Policy (London 2017).

2 For church and state under Justinian, see Karl-Heinz Uthemann, "Kaiser Justinian als Kirchenpolitiker und Theologe," Augustinianum 39, no. 1 (1999): 5-83; Hartmut Leppin, "Zu den Anfängen der Kirchenpolitik Justinians," in Staatlichkeit und politisches Handeln in der römischen Kaiserzeit, ed. Hans-Ulrich Wiemer, Millennium Studies 10 (Berlin 2006), 187-208; Hartmut Leppin, Justinian: Das christliche Experiment (Stuttgart 2011).

3 For a survey of the literature in a recent reference work, see Harold A. Drake, "Church and Empire," in Oxford Handbook of Early Christian Studies, ed. Susan Ashbrook Harvey and David G. Hunter (Oxford 2008), 446-464. For narrative approaches to this question, see Charles Pietri and Luce Pietri, eds., Das Entstehen der einen Christenheit (230-430), Die Geschichte des Christentums 2 (Freiburg im Breisgau 1995), 193-506; Luce Pietri, ed., Der lateinische Westen und der byzantische Osten (431-642), Die Geschichte des Christentums 3 (Freiburg im Breisgau 1998), 120-157, 222-231, 300-342, 421-461, 794-864; Harold A. Drake, "The Church, Society and Political Power," in Cambridge History of Christianity, vol. 2, Constantine to c. 600, ed. Augustine Casiday and Frederick W. Norris (Cambridge 2007), 403-428.

Ә Open Access. (c) 2021 Philip Michael Forness, published by De Gruyter. (c) BY-NC-ND This work is licensed under the Creative Commons Attribution-NonCommercial-NoDerivatives 4.0 International License. 
attracted attention. ${ }^{4}$ Yet Syriac sources still remain outside the purview of most studies. ${ }^{5}$ This article seeks to explain a surprising perspective on emperors found in the works of two of the most celebrated authors in the Syriac tradition: Ephrem the Syrian (c. 306-373) and Jacob of Serugh (d. 520/1). Both authors praise emperors and even the faith of emperors - with whom they disagreed theologically. The exploration of these two authors will demonstrate the value of Syriac sources for the broader investigation of Christian perspectives on rulers in late antiquity.

Ephrem the Syrian and Jacob of Serugh wrote at turning points in imperial involvement in the church. Ephrem composed five hymns that comment on the religious conduct of Emperors Constantine I, Constantius II (r. 337-361), and Julian (r. 361-363). ${ }^{6}$ Constantius became augustus when his father Constantine died in 337,

4 Four recent monographs, for example, focus on Syriac political thought: Philip Wood, "We Have No King But Christ": Christian Political Thought in Greater Syria on the Eve of the Arab Conquest (c. 400-585), Oxford Studies in Byzantium (Oxford 2010); Richard E. Payne, A State of Mixture: Christians, Zoroastrians, and Iranian Political Culture in Late Antiquity, Transformation of the Classical Heritage 56 (Berkeley 2015); Kyle Smith, Constantine and the Captive Christians of Persia: Martyrdom and Religious Identity in Late Antiquity, Transformation of the Classical Heritage 57 (Berkeley 2015); Manolis Papoutsakis, Vicarious Kingship: A Theme in Syriac Political Theology in Late Antiquity, Studien und Texte zu Antike und Christentum 100 (Tübingen 2017).

5 The lack of research on both sets of sources treated in this article regarding questions of church and state is illustrative. Major biographies of the Emperor Julian mention Ephrem the Syrian's Hymn on the Church and Hymns against Julian only in passing: Robert Browning, The Emperor Julian (Berkeley 1976), 192, 213-215, 217; Glen Warren Bowersock, Julian the Apostate (Cambridge, MA 1978), 9-10, 103-104, 114, 116, 118, 122; Klaus Bringmann, Kaiser Julian: Der letzte heidnische Herrscher (Darmstadt 2004), 182-183; Klaus W. Rosen, Julian: Kaiser, Gott und Christenhasser (Stuttgart 2006), 17-18, 289, 362, 374, 457; H. C. Teitler, The Last Pagan Emperor: Julian the Apostate and the War Against Christianity (Oxford 2017), 30, 170n6, 173n6, 179n4. Recent studies focused on politics and religion during Julian's reign only rarely incorporate Ephrem's writings: Federico Fatti, Giuliano a Cesarea: La politica ecclesiastica del principe apostata, Studi e testi tardoantichi 10 (Rome 2009), 126n98, 143n16; Susanna Elm, Sons of Hellenism, Fathers of the Church: Emperor Julian, Gregory of Nazianzus, and the Vision of Rome, Transformation of the Classical Heritage 49 (Berkeley 2012), 371n119, 424n147, 447, 450. The lack of attention to the Hymns against Julian seems surprising, given their incorporation in 1989 into a collection of texts related to Julian's reign in English translation: Samuel N. C. Lieu, ed., The Emperor Julian: Panegyric and Polemic, Translated Texts for Historians 2 (Liverpool 1989), 105-127. Jacob of Serugh's Letters had been published but not fully translated when the last major treatment of Justin's reign appeared: A. A Vasiliev, Justin the First: An Introduction to the Epoch of Justinian the Great, DOS 1 (Cambridge, MA 1950).

6 Ephrem the Syrian, Hymn on the Church (Edmund Beck, ed. and trans., Des Heiligen Ephraem des Syrers Hymnen de Paradiso und Contra Julianum, CSCO 174-175, Scr. Syri 78-79 [Leuven: Secrétariat du CorpusSCO, 1957], CSCO 174, Scr. Syri 78:67-70); Hymns against Julian 1-4 (Beck, CSCO 174, Scr. Syri 78:71-90). Various translations of the set have appeared, among which see Gustav Bickell, "Die Gedichte des hl. Ephräm gegen Julian den Apostaten”, Zeitschrift für katholische Theologie 2, no. 2 (1878): 337-356; Beck, CSCO 175, Scr. Syri 79:61-86; Lieu (cf. fn. 4) 105-127 (only the four Hymns against Julian); Kathleen E. McVey, trans., Ephrem the Syrian: Hymns, Classics of Western Spirituality (New York 1989), 221-257. The recent Russian translation could unfortunately not be consulted: 
and he was the sole Roman Emperor after defeating Magnentius (r. 350-353) who had overthrown Constantius's brother Constans I (r. 337-350). Constantius supported the anti-Nicene, so-called "Homoeans" in his pursuit of church unity, ${ }^{7}$ and he became known especially for sending pro-Nicene bishops such as Athanasius of Alexandria (c. 295-373) and Hilary of Poitiers (c. 295-373) into exile. ${ }^{8}$ Constantius appointed Julian as caesar in 355, and Julian became sole emperor on Constantius's death in 361. Julian's policies aimed towards restoring traditional Roman piety earned him the scorn of Christians in his time, Ephrem the Syrian among them.

Jacob of Serugh authored two letters in response to the changes in ecclesiastical policy early in the reign of Justin I (r. 518-527). ${ }^{9}$ Parties opposed to the Christology of the Council of Chalcedon in 451 had enjoyed a certain level of success during the long reign of Anastasius I (r. 491-518). ${ }^{10}$ Yet the imperial church's position on the

Alexey Muraviev, Мар Афрем Нисибинский (Прп. Ефрем Сирин): Юлиановский Цикл, Smaragdos Philocalias (Moscow 2006).

7 On Constantius's support for Homoean views, see Richard Klein, Constantius II. und die Christliche Kirche (Darmstadt 1977), 16-67; Hanns Christof Brennecke, Studien zur Geschichte der Homöer: Der Osten bis zum Ende der homöischen Reichskirche, Beiträge zur historischen Theologie 73 (Tübingen 1988), 5-86. The anti-Nicene church historian Philostorgius portrays Constantius as a saint, as explored in Bruno Bleckmann, "Das Bild des Constantius in der Kirchengeschichte des Philostorgios," in Le Prince chrétien de Constantin aux royautés barbares (IV - VIII siècle), ed. Sylvain Destephen, Bruno Dumézil, and Hervé Inglebert, Travaux et mémoires 22/2 (Paris 2018), 127-136.

8 On his engagement in ecclesiastical affairs, see especially Steffen Diefenbach, "Constantius II. und die „Reichskirche“ - ein Beitrag zum Verhältnis von kaiserlicher Kirchenpolitik und politischer Integration im 4. Jh.," Millennium 9, no. 1 (2012): 59-121. On his relationships with Athanasius and Hilary, see Hanns Christof Brennecke, Hilarius von Poitiers und die Bischofsopposition gegen Konstantius II: Untersuchungen zur dritten Phase des arianischen Streites (337-361), Patristische Texte und Studien 26 (Berlin 1984); Timothy David Barnes, Athanasius and Constantius: Theology and Politics in the Constantinian Empire (Cambridge 1993), 144-151.

9 Jacob of Serugh, Letters 32 (Gunnar Olinder, ed., Iacobi Sarugensis epistulae quotquot supersunt, CSCO 110, Scr. Syri 57 [Leuven 1937], 238-241); 35 (Olinder, CSCO 110, Scr. Syri 57:257-260). For translations of these letters in German, French, and Italian, see Severin Matthias Grill, trans., Jakob von Sarug: Ausgewählte Briefe, Heiligenkreuzer Studien 17 (Heiligenkreuz 1971-1972), 3:32-35, 3840; Micheline Albert, trans., Les lettres de Jacques de Saroug, Patrimoine Syriaque 3 (Kaslik, Lebanon 2004), 316-322, 338-341; Behnam M. Boulos Sony, trans., Lettere di Giacomo vescovo di Sarug, 451-521 a.d. (Rome 2008), 396-400, 410-413. An Arabic translation of Jacob of Serugh's letters has also appeared, but I have not consulted it for this article: Behnam M. Boulos Sony, trans., Rasā’il Mār Ya'qūb al-surūji al-malfān, 2 vols., Mawsū'at 'uzamamā' al-masīhīiyyah fĩ al-tārīḳ: dirāsāt mutaǩașșișah 3-4 (Dekwaneh, Lebanon 1995).

10 On Anastasius's religious policy, see Peter Charanis, Church and State in the Later Roman Empire: The Religious Policy of Anastasius the First, 491-518, University of Wisconsin Studies in the Social Sciences and History 26 (Madison, WI 1939); Carmelo Capizzi, L'imperatore Anastasio I (491518): Studio sulla sua vita, la sua opera e la sua personalità, OCA 184 (Rome 1969), 100-137; F. K. Haarer, Anastasius I: Politics and Empire in the Late Roman World, ARCA Classical and Medieval Texts, Papers and Monographs 46 (Cambridge 2006), 115-183; Mischa Meier, Anastasios I.: Die Entstehung des Byzantinischen Reiches (Stuttgart 2009), 38-52, 250-319. 
Council of Chalcedon changed very soon after Anastasius's death on the night of July 8th to 9th, 518. ${ }^{11}$ After the army proclaimed Justin emperor on July 9th or 10th, a group of laity gathered on July 15th in the Great Church in Constantinople to demand acceptance of the Council of Chalcedon, the denouncement of its detractors, the reinstatement of pro-Chalcedonian bishops to their sees, and the restoration of the names of pro-Chalcedonian leaders to the diptychs. The patriarch of Constantinople succumbed to their request to celebrate a liturgy in honour of the council on the following day. Petitions sent by a group of monks along with the demands of the laity were considered and affirmed at a synod held in Constantinople on July 20th. ${ }^{12}$ Shortly thereafter, the patriarch wrote letters to provinces throughout the Roman Near East seeking their acceptance of these decisions. ${ }^{13}$ The measures that Justin took to compel adherence to Chalcedonian Christology following this synod affected the Roman Near East in a particularly strong way during Jacob of Serugh's lifetime, as explored below.

Although Ephrem disagreed with the theological views of Constantius and Jacob with those of Justin, these authors portray the emperors in a positive light and even laud the content of their faith. An examination of the circumstances of composition of these works will help to clarify these apparent contradictions. This analysis, as I

11 On the events summarised in this paragraph, see Sévérien Salaville, "La fête du concile de Nicée et les fêtes de conciles dans le rit byzantin,” EO 24, no. 140 (1925): 455-461; Vasiliev (cf. fn. 5) 132148; Sévérien Salaville, "La fête du concile de Chalcédoine dans le rite byzantine," in Das Konzil von Chalkedon: Geschichte und Gegenwart, ed. Alois Grillmeier and Heinrich Bacht, vol. 2 (Würzburg 1953), 681-687; William H. C. Frend, The Rise of the Monophysite Movement: Chapters in the History of the Church in the Fifth and Sixth Centuries (Cambridge 1972), 233-234; Milton V. Anastos, "The Emperor Justin I's Role in the Restoration of Chalcedonian Doctrine, 518-519," Byzantina 13, no. 1 (1985): 128-134; Alois Grillmeier, Christ in Christian Tradition, vol. 2, From the Council of Chalcedon (451) to Gregory the Great (590-604), part 1, Reception and Contradiction: The Development of the Discussion about Chalcedon from 451 to the Beginning of the Reign of Justinian, trans. Pauline Allen and John Cawte (London 1987), 318-322; J. Speigl, "Synoden im Gefolge der Wende der Religionspolitik unter Kaiser Justinos (518)," Ostkirchliche Studien 45 (1996): 8-20; Brian Croke, "Justinian under Justin: Reconfiguring a Reign," BZ 100, no. 1 (2007): 26-27.

12 Four texts preserved in the fifth session of the Acts of the Synod of Constantinople in 536 form the primary witnesses to the events that followed shortly after Justin I's enthronement: the Request of Clergy and Monks of Antioch (Eduard Schwartz, ed., ACO [Berlin 1914-1940], 3:60-62); the Relation of the endemousa Synod of Constantinople to the Patriarch John (Schwartz, ACO 3:62-66); the Petition of the Monks to the Synod (Schwartz, ACO 3:67-71); and the Acclamations of the People and Addresses of the Bishops (Schwartz, ACO 3:71-76).

13 John II of Constantinople, Letter to John III of Jerusalem (Schwartz, ACO 3:76); John II of Constantinople, Letter to Epiphanios of Tyre (Schwartz, ACO 3:77). The title assigned to the first of these letters indicates that it was sent to bishops other than John III of Jerusalem as well (Schwartz, ACO, 3:76): “... written to John of holy memory, who was the archbishop of Jerusalem, and to all the metro-

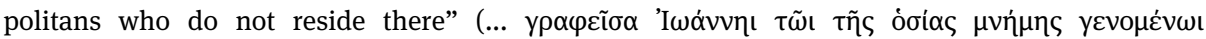

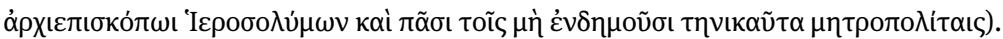


will argue in the conclusion, should encourage circumspection in identifying texts as evidence of political thinking. In this way, the study of the perspectives of authors writing from the eastern border of the Roman Empire has implications for our understanding of the relationship between church and state in antiquity more broadly.

\section{Ephrem the Syrian: Hymns against Julian}

Ephrem the Syrian lived on the border of the Roman and Persian Empires for most of the fourth century. ${ }^{14}$ His extensive corpus includes poetic hymns and homilies as well as prose writings on exegesis and theology. ${ }^{15}$ He spent most of his ecclesiastical career in the city of Nisibis under various bishops. Beginning in March 363, the Emperor Julian led an expedition against the Sasanian Empire in Mesopotamia. Julian died during a conflict in June 363. The army quickly chose Jovian (r. 363-364) as the new emperor. Jovian was forced shortly thereafter to surrender Mesopotamia, including Ephrem's Nisibis, to the Persians. Ephrem along with his community had to relocate westward to the city of Edessa. This event, the deportation of the Nisibene community, confronted Ephrem with the consequences that imperial actions could have for his local community. ${ }^{16}$

Ephrem wrote a series of hymns that comment on the hardships experienced directly before and after his community's expulsion from Nisibis. The first has no title in the manuscript but is commonly known as the Hymn on the Church. The other four form a series named the Hymns against Julian. The dating of these texts remains a matter of debate. Most recently, Manolis Papoutsakis has dated the third hymn to between 366 and 370 based on Ephrem's use of Gregory of Nazianzus's (329/30-c. 390) fifth Oration, itself composed in late 365 or early $366 .{ }^{17}$ The five hymns appear

14 There are few reliable facts about Ephrem the Syrian's life. For recent summaries, see Sebastian P. Brock, "In Search of Saint Ephrem," Khristianskij Vostok 6 (XII) (2013): 13-25; Jeffrey Wickes, trans., St. Ephrem the Syrian: The Hymns on Faith, Fathers of the Church 130 (Washington, D.C. 2015), 5-14.

15 For a list of Ephrem's works with their editions and translations, see Brock (cf. fn. 14) 25-77.

16 On Nisibis and Edessa around Ephrem's lifetime, see J. M. Fiey, Nisibe, métropole syriaque orientale et ses suffragants des origines à nos jours, CSCO 388, Subsidia 54 (Leuven 1977), 21-38; J. B. Segal, Edessa: “The Blessed City” (Oxford 1970), 110-191. For studies on Ephrem's various relationships to these cities, see Sidney H. Griffith, "Ephraem, the Deacon of Edessa, and the Church of the Empire," in Diakonia: Studies in Honor of Robert T. Meyer, ed. Thomas Halton and Joseph P. Williman (Washington, D.C. 1986), 22-52; Paul S. Russell, "Nisibis as the Background to the Life of Ephrem the Syrian," Hugoye: Journal of Syriac Studies 8, no. 2 (2005): 179-235.

17 Papoutsakis (cf. fn. 4) 135-137; Manolis Papoutsakis, "Is He the Rider of the Quadriga?: Ephrem the Syrian on Julian's Apotheosis," Adamantius 24 (2018): 399. For other proposals on dating the 
together in the one sixth-century manuscript that preserves them, ${ }^{18}$ and a colophon after the last hymn marks the five as a set: "The end of the five hymns on the Emperor Julian, the pagan." ${ }^{19}$ Here Ephrem laments the sufferings of his community while also reflecting on the failures of Julian. In addition to selections from Ephrem's other cycles of hymns, ${ }^{20}$ several studies have treated these hymns as key places for understanding Ephrem's political thought. ${ }^{21}$ I will return to the most recent scholarship on his political thought after an examination of Ephrem's perspectives on Roman Emperors in these hymns.

\subsection{Contrasting Images of Constantius II and Julian}

Each of Ephrem's five hymns written around the time of the loss of the city of Nisibis has its own narrative structure. The Hymn on the Church seems to come from the time of Julian's rule. Ephrem seeks to comfort his audience by pointing to biblical figures who remained faithful under idolatrous rulers. The first Hymn against Julian describes Julian's death as just vengeance and suggests that the forces of good have allied against those of evil. The second Hymn against Julian focuses on historical events from Julian's tenure, especially regarding his support for the rebuilding of the temple in Jerusalem and contrasts him with his predecessor Constantius. The

hymns, see Browning (cf. fn. 5) 213; Sidney H. Griffith, "Ephraem the Syrian’s Hymns against Julian: Meditations on History and Imperial Power,” VChr 41, no. 3 (1987): 238.

18 A colophon dates the manuscript - London, British Library, Add. 14571 - to the year 519 (William Wright, Catalogue of Syriac Manuscripts in the British Museum Acquired since the Year 1838 [London, 1870-1872], 2:410-413).

19 علم sa.ïr (Beck, CSCO 174, Scr. Syri 78:91).

20 Ignacio Ortiz de Urbina, “L’èvêque et son role d'après saint Éphrem," Parole de l'Orient 4.1 (1973): 137-146, is the first study dedicated to Ephrem's political thought. He focuses on Ephrem the Syrian, Carmina nisibena 21.21, 23 (Edmund Beck, ed. and trans., Carmina nisibena, CSCO 218-219, 240-241, Scr. Syri 92-93, 102-103 [Leuven 1961-1963], CSCO 218, Scr. Syri 92:58-59). Griffith (cf. fn. 16) discusses this same passage as well as Ephrem the Syrian, Hymns on the Faith 20.23 (Edmund Beck, ed. and trans., Des heiligen Ephraem des Syrers Hymnen de fide, CSCO 154-155, Scr. Syri 73-74 [Leuven 1955], CSCO 154, Scr. Syri 73:271). Andrew Palmer, “The Prophet and the King: Mår Afrem’s Message to the Eastern Roman Emperor," in After Bardaisan: Studies on Continuity and Change in Syriac Christianity in Honour of Professor Han J. W. Drijvers, ed. G. J. Reinink and A. C. Klugkist, Orientalia Lovaniensia Analecta 89 (Leuven 1999), 213-236, focuses especially on Hymns on the Faith 8.10-11 (Beck, CSCO 154, Scr. Syri 73:39-40). Manolis Papoutsakis, "The Making of a Syriac Fable: From Ephrem to Romanos,” Mus 120, no. 1-2 (2007): 31-37, treats Ephrem the Syrian, Hymns on the Nativity 6 (Edmund Beck, ed. and trans., Des Heiligen Ephraem des Syrers Hymnen de Nativitate (Epiphania), CSCO 186-187, Scr. Syri 82-83 [Leuven 1959], CSCO 186, Scr. Syri 82:50-55). The works treated in Papoutsakis, Vicarious Kingship (cf. fn. 4) are too numerous to list here.

21 See Griffith (cf. fn. 16) 36; Papoutsakis (cf. fn. 4) 87-91, 119-120; Papoutsakis (cf. fn. 17); Papoutsakis (cf. fn. 20) 45. 
third and fourth Hymns against Julian suggest why God allowed Julian's paganism to come to the fore, that is, on Ephrem's view, so that paganism might be rebuked and thwarted. These five hymns form a set through their topical similarity, their use of the same poetic meter, and their manuscript transmission..$^{22}$ Their unity appears strongly in their common use of a defined set of symbols drawn from the biblical text and the natural world. ${ }^{23}$ An examination of the employment of such imagery allows a clearer articulation of Ephrem's views on Roman Emperors in these five hymns.

In his Hymn on the Church, Ephrem draws on the imagery of a vine. This "vine symbolism" ${ }^{24}$ has its origin in the Hebrew Bible and in Jesus's description of the true vine in John 15:1-8. ${ }^{25}$ Ephrem focuses especially on the symbols of a branch, the shade it offers, and the cover it provides during time of drought. Although Ephrem does not name Julian in the Hymn on the Church, the criticisms he makes of an unidentified emperor suggest that he has Julian in mind. He summons biblical narratives to show his contempt. The 7,000 people who did not bow down to Baal during the reign of Ahab and Jezebel show that God uses wicked rulers to test the true (1 Kgs 19:18; Rom 11:4). ${ }^{26}$ The story of Daniel and his three friends during Nebuchadnezzar's reign demonstrates that God destroys the acts of those who worship false gods (Dn 3:8-30). ${ }^{27}$ Yet, at the end of the hymn, he surprisingly praises not only Constantine but also Constantius, who supported parties that opposed the Nicene theology to which Ephrem himself adhered:

The emperors who provided shade quenched us in the droughts,

We ate their fruits [but] we despised their branches.

Our soul revelled in the blessings and shadows.

Our mouth raged and attacked our creator. ${ }^{28}$

The emperors' actions celebrated in this strophe are the same actions for which Ephrem commemorates Christ and the church earlier in the hymn. Christ or the church also provided shade upon the earth, ${ }^{29}$ quenched the furnace for Daniel's

22 Beck, CSCO 174, Scr. Syri 78:i-ii.

23 On this tendency in general, see Robert Murray, Symbols of Church and Kingdom, rev. ed. (London 2006), first published in 1975; Sebastian P. Brock, The Luminous Eye: The Spiritual World Vision of Saint Ephrem, Cistercian Studies 124 (Kalamazoo, MI 1992).

24 Murray (cf. fn. 23) 106.

25 Murray (cf. fn. 23) 97-99.

26 Ephrem the Syrian, Hymn on the Church 4 (Beck, CSCO 174, Scr. Syri 78:67-68).

27 Ephrem the Syrian, Hymn on the Church 6-7 (Beck, CSCO 174, Scr. Syri 78:68).

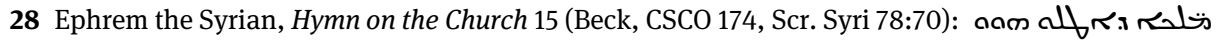

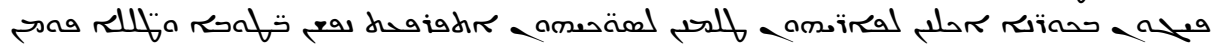
همi. I follow McVey (cf. fn. 6) 225, on the translation of صrm.

29 Ephrem the Syrian, Hymn on the Church 9 (Beck, CSCO 174, Scr. Syri 78:69), claims that the branch of truth (i.e., Christ or the church) "conquered all kings and provided shade over the whole 
friends, ${ }^{30}$ and grew fruit to satisfy the ungrateful. ${ }^{31}$ Ephrem remarkably applies the vine imagery usually reserved for God and leaders of the church to both Constantine and Constantius. He makes a striking contrast between the Emperor Julian whom he condemns and the Emperors Constantine and Constantius who receive praise for providing protection and peace.

Ephrem also uses pastoral imagery throughout this set of hymns. This imagery derives from Jesus's self-description as the Good Shepherd (Jn 10:11, 14), from Jesus's commandments to Peter in which he calls his followers sheep (Jn 21:15-17), ${ }^{32}$ and from an epithet of King David. ${ }^{33}$ This set of imagery includes words such as

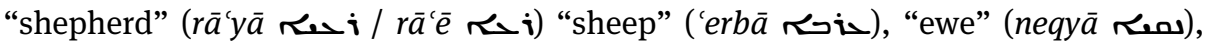

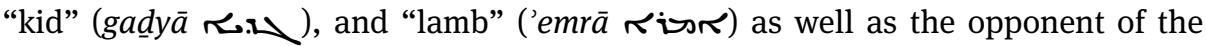

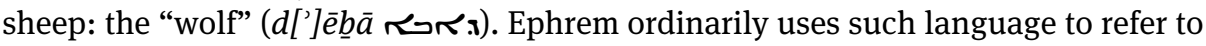
Christ and the ecclesiastical hierarchy. ${ }^{34}$ But here he applies pastoral imagery to the duties of emperors. In the first Hymn against Julian, for example, he lists the responsibilities of true rulers: "The sceptre of the kingdom which shepherds humanity, / attends to cities, and chases away animals...." ${ }^{35}$ Later in this hymn, Ephrem speci-

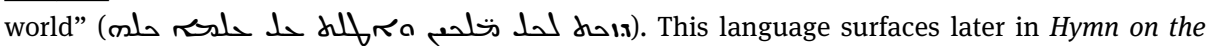
Church 15 (Beck, CSCO 174, Scr. Syri 78:70), when Ephrem writes that Julian "removed our shade"

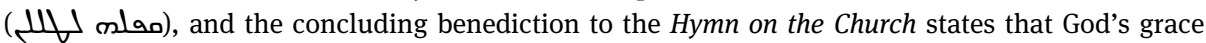

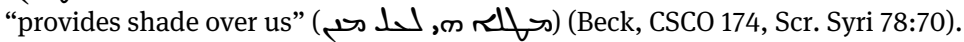

30 Ephrem the Syrian, Hymn on the Church 7 (Beck, CSCO 174, Scr. Syri 78:68), states that the branch (i.e., Christ) "quenched the furnace" (radir , (a) for Daniel's friends.

31 Ephrem the Syrian, Hymn on the Church 8 (Beck, CSCO 174, Scr. Syri 78:68), speaks of "that branch [i.e., Christ or the church] that bent down its fruits to the ungrateful" ( ה

32 Murray (cf. fn. 23) 187, states that the biblical origins of the shepherd and its counterpart, flock, come from "the Old Testament, where both God and the king are called shepherd of God's people, and in the New, where Christ, the 'Good Shepherd,' entrusted his sheep to Peter, and in turn 1 Peter 5:2-4 exhorts the clergy to 'tend the flock' in such a way as to earn commendation from the 'Chief Shepherd."”

33 In this regard, Papoutsakis (cf. fn. 4) 88, lists 1 Samuel 16:11; 2 Samuel 5:2; 1 Chronicles 11:2; Ezekiel 32:23; 37:24. Such imagery is also used in reference to Cyrus the Great in Isaiah 44:28.

34 He usually uses this symbol to refer to Christ or to bishops, as Murray (cf. fn. 23) 191, has shown. For examples of Christ as shepherd (i i 3.15, 4.128, 7.5, 8.6, 11.6 (Beck, CSCO 186, Scr. Syri 82:1, 23, 37, 56, 60, 70). For examples of church

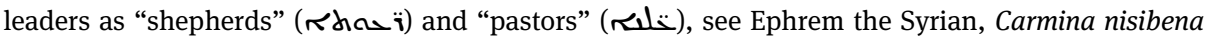
14.1; 17.1, 3-4 (Beck, CSCO 218, Scr. Syri 92:37, 46). For examples of congregations as "flocks" (Sh), see Ephrem the Syrian, Carmina nisibena 19.1, 3, 6, 14 (Beck, CSCO 218, Scr. Syri 92:50$51,53)$.

35 Ephrem the Syrian, Hymns against Julian 1.1 (Beck, CSCO 174, Scr. Syri 78:71): 
fies that Julian has failed to wield this sceptre rightly ${ }^{36}$ and as a result the Persians have "surrounded the blessed flock." ${ }^{37}$ Ephrem criticises Julian for failing to carry out one of the fundamental responsibilities of emperors: protecting the area under their control from enemies.

In the next hymn, Ephrem explicitly contrasts the actions of Constantius and Julian in fulfilling their roles as shepherds. He writes:

The wolf was borrowing the clothing of the true lamb.

The innocent sheep sniffed him, but they did not recognise him.

He greatly deceived that shepherd who departed [this life]. ${ }^{38}$

A defensible interpretation of these lines runs as follows. The first line describes Julian, here called the "wolf," and his deceitful actions in becoming the Roman Emperor. The "innocent sheep" in the second line represent the Christian community or people living under Roman rule more broadly who fail to recognise Julian for what he is. The third line proves most relevant for the present discussion. Here Julian escapes the notice of another shepherd - Constantius - who has just died. Constantius was apparently the shepherd of these innocent sheep and was deceived into believing that Julian was a Christian. The remainder of the passage describes the consequences of the failure of the Christian community and Constantius to notice who Julian really was. ${ }^{39}$ Despite Constantius's deception by Julian, Ephrem assigns Constantius the title of shepherd contrasting him with Julian, the wolf in sheep's clothing. Only the true shepherd, that is, the true emperor, could fulfil his responsibility to protect his flock.

36 Ephrem the Syrian, Hymns against Julian 1.1 (Beck, CSCO 174, Scr. Syri 78:71): "Its opposite was

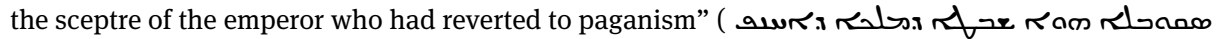
ram).

37 Ephrem the Syrian, Hymns against Julian 1.2 (Beck, CSCO 174, Scr. Syri 78:71):

محis

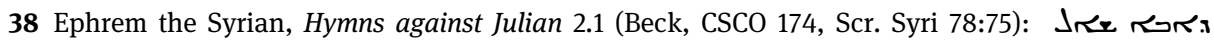

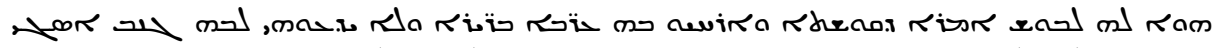

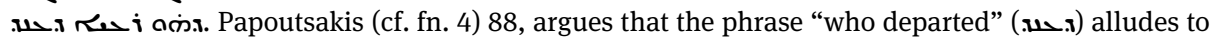
Genesis 49:10: "the sceptre will not depart from Judah" (Jaeke Jansma and The Peshițta Institute Leiden, eds., "Genesis," in The Old Testament in Syriac according to the Peshitta Version, vol. 1.1 [Leiden 1982], 112). Thus, within the eschatological interpretation of this passage, Ephrem portrays Julian as the one who breaks off the succession of good emperors beginning with Constantine and Constantius. Papoutsakis suggests that this phrase should be understood fully as "that shepherd upon whose departing the new Davidic line was cut off."

39 Ephrem the Syrian, Hymns against Julian 2.1 (Beck, CSCO 174, Scr. Syri 78:75): "The wolf came out from within the lamb. / He took off [and] threw away his beauty. / The kids caught his scent. /

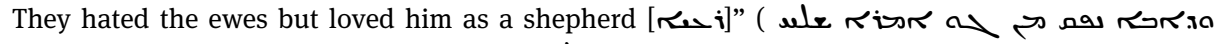

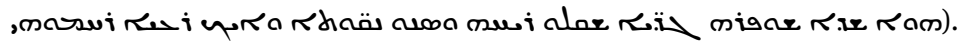


The final type of imagery examined here is Ephrem's use of biblical typology to malign and praise emperors. In the second hymn, he compares Julian to "Ahab and Jeroboam, Jotham and Manasseh, Jezebel and Athaliah," whom he calls "founts of godlessness." ${ }^{40} \mathrm{He}$ also describes Julian's fall in relation to the narrative of Nebuchadnezzar and to the deaths of the maligned Antiochus IV Epiphanes (r. 175-164 BCE) and Herod Agrippa I (r. 41-44 CE). ${ }^{41}$ Most significant for this article, in the second hymn Ephrem contrasts the behaviour of Julian and Constantius through the figure of the king of Nineveh from the book of Jonah. He focuses on the iconic image of the king ordering both people and animals to be covered in sackcloth (Jon 3:8). ${ }^{42}$ Under Julian's reign, Ephrem suggests, God allowed Nisibis to be ceded to Persia in

40 Ephrem the Syrian, Hymns against Julian 2.2 (Beck, CSCO 174, Scr. Syri 78:76): "They [i.e., the Jews] rejoiced that [Julian] had filled the place of many: / Of the kings and the queens who were like / Ahab and Jeroboam, Jotham and Mannaseh, / Jezebel and Athaliah - the founts of godlessness"

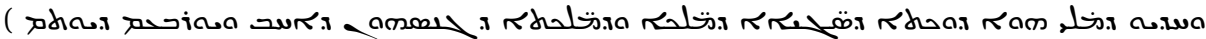

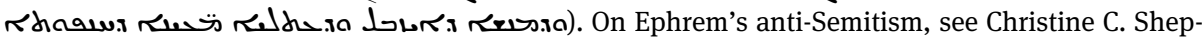
ardson, Anti-Judaism and Christian Orthodoxy: Ephrem's Hymns in Fourth-Century Syria, Patristic Monograph Series 20 (Washington, D.C. 2008).

41 Ephrem the Syrian, On the Church 7 (Beck, CSCO 174, Scr. Syri 78:68), alludes to Nebuchadnezzar's altercation with Daniel and the three men to reveal the powerlessness of rulers like Julian: "The arms of the conqueror were conquered, for he threatened / That his highness would have to

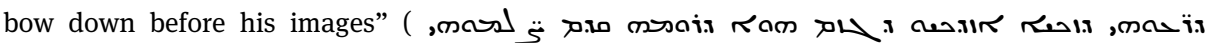
, (ن حسח). Nebuchadnezzar's repentance also forms a foil for Julian: Ephrem the Syrian, Hymns against Julian 1.18 (Beck, CSCO 174, Scr. Syri 78:74), writes that unlike Julian he "learned to be subdued" (ملف xar), and in Hymns against Julian 1.20 (Beck, CSCO 174, Scr. Syri 78:75), God

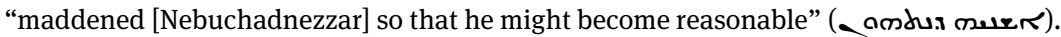

On Antiochus and Herod, I will briefly summarise the findings of Papoutsakis (cf. fn. 20) 45-46; Papoutsakis (cf. fn. 4) 124-125. Ephrem the Syrian, Hymns against Julian 4.3 (Beck, CSCO 174, Scr. Syri 78:85), describes the death of Julian's namesake uncle: "[Julian] also caught a glimpse of his kinsmen in his kinsman, / Who bred worms, while still alive, and crumbled away" ( am ar

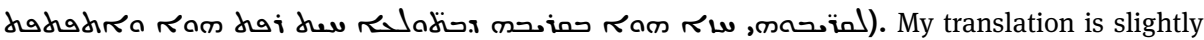
modified from that found in Papoutsakis (cf. fn. 20) 45. The phrase "who bred worms, while still alive" (Ram hai hew racalls the description of Antiochus's death in 2 Maccabees 9:9: "So severe was the suffering of the wicked man that even worms bred from his body. Although he

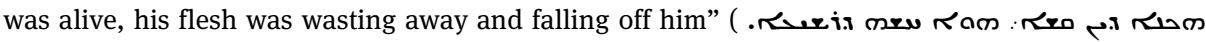
(Angelo Penna, Konrad Dirk Jenner, and D. Bakker, eds., "1-2 Maccabees," in The Old Testament in Syriac according to the Peshitta Version, vol. 4.4 [Leiden 2013], 175). It also alludes to the description of Herod's death in Acts 12:23 in which he is said to have "bred worms and died" ( dusa) (The New Testament in Syriac [London 1905-1920], 21).

42 Jonah 3:8: "But people and animals shall be covered with sackcloth" ( مله

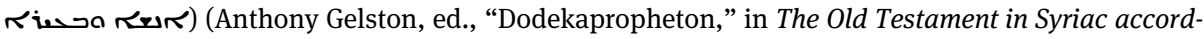
ing to the Peshitta Version, vol. 3.4 [Leiden 1980], 43). Sackcloth appears elsewhere in the Hebrew Bible in mourning rituals. But in no other passage is it so clearly associated with the (successful) preservation of a city as in Jonah. 
order to reveal the futility of Julian's piety, that is, traditional Roman piety. ${ }^{43}$ Yet Constantius, as Ephrem suggests, preserved the city "by his sackcloth," that is, by the penitential garments that the king of Nineveh and his subjects wore in Jonah. ${ }^{44}$

Ephrem draws on the imagery of sackcloth later in the same hymn. He writes: "As for the walled city which was the head of the region of Mesopotamia, / The sackcloth of the blessed one preserved it and it was exalted. / The tyrant by his blasphemy made it bow down, and it was overcome." 45 The terms "tyrant" and "sackcloth" in this quotation deserve special attention. First, the Syriac term translated here as "tyrant” (tronā raib) is a loan word from Greek (túrannos túpavvos) that carries the meaning of illegitimate rule. ${ }^{46}$ The Greek epithet is applied to Julian in two Orations of Gregory of Nazianzus ${ }^{47}$ and the Ecclesiastical History of Theodoret of Cyrrhus (c. 393-c. 466). ${ }^{48}$ Significantly, the Syriac Peshițta translation of 2 and 4 Maccabees employs this title in reference to Antiochus IV Epiphanes. ${ }^{49}$ Ephrem uses

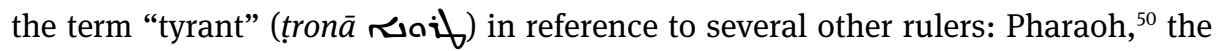

43 Ephrem the Syrian, Hymns against Julian 2.16 (Beck, CSCO 174, Scr. Syri 78:79).

44 Ephrem the Syrian, Hymns against Julian 2.19 (Beck, CSCO 174, Scr. Syri 78:79): כعר סمמש

45 Ephrem the Syrian, Hymns against Julian 2.25 (Beck, CSCO 174, Scr. Syri 78:80-81):

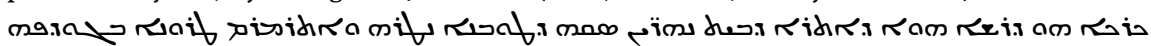

.dadrara

46 On this, see especially the explanation in Henry George Liddell and Robert Scott, An Intermediate Greek-English Lexicon (New York, 1889), 824-825: “not applied to old hereditary sovereignties ( $\beta \alpha \sigma ı \lambda \varepsilon \tilde{\alpha} \alpha$ ı) such as those of Hom. or of Sparta; for the term rather regards the irregular way in which the power was gained, than the way in which it was exercised, being applied to the mild Pisistratus, but not to the despotic kings of Persia." See also Henry George Liddell, Robert Scott, and Henry Stuart Jones, A Greek-English Lexicon, new rev. ed. (Oxford 1961), 1836; G. W. H. Lampe, A Patristic Greek Lexicon (Oxford 1961), 1421.

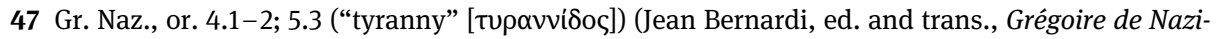
anze: Discours 4-5, SC 309 [Paris 1983], 86, 88, 298). I am grateful to Hartmut Leppin for the references to Gregory's and Theodoret's use of the language of tyranny in relation to Julian.

48 Theod., hist. eccl. 3.11.1; 3.16.6; 3.28.3; 4.1.3 (Léon Parmentier and Günther Christian Hansen, eds., Theodoret: Kirchengeschichte, GCS, n.F. 5 [Berlin 1998], 187, 195, 206, 210).

49 The mother of the seven boys that are killed uses this word in relation to Antiochus in 2 Maccabees 7:27 (Penna, Jenner, and Bakker [cf. fn. 41] 168). The book of 4 Maccabees retells this story in more detail and repeatedly uses "tyrant" ( $\sim \circ \downarrow$ ) to refer to Antiochus. The first instances appear in 4 Maccabees 1:11; 5:1, 4-5, 14 (Robert Lubbock Bensly and W. Emery Barnes, The Fourth Book of

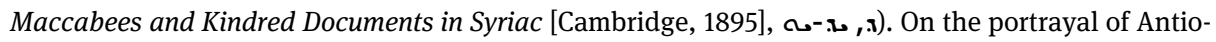

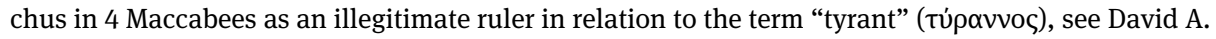
deSilva, 4 Maccabees: Introduction and Commentary on the Greek Text in Codex Sinaiticus, Septuagint Commentary Series (Leiden 2006), 125-27. The date at which 2 and 4 Maccabees were translated into Syriac remains unclear. However, it seems likely that they were undertaken in the fourth century at the latest when the cult of the Maccabees was rising to prominence.

50 Ephrem the Syrian, Hymns on Virginity 10.4 (Edmund Beck, ed. and trans., Des heiligen Ephraem des Syrers Hymnen de virginitate, CSCO 223-224, Scr. Syri 94-95 [Leuven 1962], CSCO 223, Scr. Syri 
five lords of the Philistines, ${ }^{51}$ Nebuchadnezzar, ${ }^{52}$ and Herod Antipas (r. c. 4 BCE-39 CE). ${ }^{53}$ Manolis Papoutsakis has demonstrated the link between Herod the Great ( $r$. 37-4 BCE), the father of Herod Antipas, and Julian as illegitimate rulers in Ephrem's thought. ${ }^{54}$ Ephrem's application of this term to Julian three times in his Hymns against Julian seems to link his reign to that of other illegitimate rulers, such as Antiochus IV and the Herodian line..$^{55}$

Second, the precise meaning of the word "sackcloth" (saqqā (ممك ) in this quotation remains unclear. Ephrem contrasts Constantius's “sackcloth" with Julian's blasphemy, indicating that sackcloth refers to the opposite of blasphemy. "Reverence" or "piety" seems a likely interpretation. ${ }^{56}$ Decades later, Emperor Theodosius I (r. 379-395) was forced to do penance following a massacre at Thessaloniki for which Ambrose of Milan (c. 339-397) held him responsible. Literary sources claim that he had to take off his imperial garments in performing the penitential act. The model in these sources seems to be King David. ${ }^{57}$ By way of contrast, Ephrem compares Constantius to the king of Nineveh. Just as the king of Nineveh led people and animals to repent, so did the blessed Constantius save the centre of Christianity in Mesopotamia through his piety, in stark contrast to his successor, the illegitimate ruler Julian.

94:34); Sermons on Holy Week 6.269 (Edmund Beck, ed. and trans., Ephraem Syrus: Sermones in Hebdomadam Sanctam, CSCO 412-413, Scr. Syri 181-182 [Leuven 1979], CSCO 412, Scr. Syri 181:46).

51 Ephrem the Syrian, Hymns on the Faith 8.12 (Beck, CSCO 154, Scr. Syri 73:40). Here he follows the Peshitta translation of the Hebrew Bible, which regularly use this term to refer to "the rulers of the

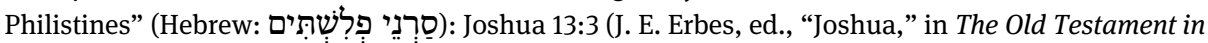
Syriac according to the Peshitta Version, vol. 1.2 \& 2.1b [Leiden 1991], 33); Judges 3:3; 16:5, 8, 18 (2x), 23, 27, 30 (Piet B. Dirksen, ed., "Judges," in The Old Testament in Syriac according to the Peshitta Version, vol. 2.2 [Leiden 1978], 7, 44-47); 1 Samuel 5:8, 11; 6:4 (2x), 12, 16, 18; 7:7; 29:2, 6-7 (P. A. H. de Boer, ed., "Samuel," in The Old Testament in Syriac according to the Peshitta Version, vol. 2.2 [Leiden 1978], 12-15; 73-74); Sirach 46:18 (Milan, Biblioteca Ambrosiana, B. 21 inf., fol. 236r; Paul de Lagarde, Libri Veteris Testamenti apocryphi syriace [Leipzig 1861], 46).

52 Ephrem the Syrian, Carmina nisibena 34.6 (Beck, CSCO 219, Scr. Syri 92:102); Hymns on Fasting 7.14 (Edmund Beck, ed. and trans., Des heiligen Ephraem des Syrers Hymnen de ieiunio, CSCO 246247, Scr. Syri 106-107 [Leuven 1964], CSCO 246, Scr. Syri 106:22).

53 Ephrem the Syrian, Hymns on the Nativity 4.62, 66, 72, 74; 24.1, 6, 9; 25.4 (Beck, CSCO 186, Scr. Syri 82:31-32, 121-123, 128).

54 Manolis Papoutsakis (cf. fn. 20) 41-45.

55 In addition to the passage discussed in this paragraph, see Ephrem the Syrian, Hymns against Julian 1.13; 2.19 (Beck, CSCO 174, Scr. Syri 78:73, 79).

56 As suggested by McVey (cf. fn. 6) 240n94.

57 On this important episode and for references to primary sources see F. Kolb, "Der Bussakt von Mailand: Zum Verhältnis von Staat und Kirche in der Spätantike," in Geschichte und Gegenwart: Festschrift für Karl Dietrich Erdmann, ed. Hartmut Boockmann (Neumünster 1980), 41-74; Neil McLynn, Ambrose of Milan: Church and Court in a Christian Capital, Transformation of the Classical Heritage 22 (Berkeley 1994), 315-330; Hartmut Leppin, Theodosius der Große, Gestalten der Antike (Darmstadt 2003), 152-160. See also the contribution by Mikhail Boytsov in this volume. 
The three different sets of imagery examined in these hymns expose the spectrum of praise that Ephrem offers Constantius. Vine symbolism emphasises the protecting role of emperors without commenting directly on the content of their faith. The pastoral imagery of the sceptre similarly reinforces the duty of emperors to watch over their subjects. But Ephrem's assertion that Constantius was a true shepherd in contrast to Julian the wolf in sheep's clothing points to a more fundamental claim about the legitimacy of Constantius's reign. Biblical typology based on the king of Nineveh moves even further in this direction by calling Julian a "tyrant" (tronā $\sim \circ \downarrow$ ) rather than an emperor. Ephrem further contrasts Julian's blasphemy with Constantius's "sackcloth" which likely represents his piety. In these hymns, Ephrem sees Constantius as a good ruler whose reign allowed the cities in his empire to flourish. And, at one point, he even seems to commend Constantius's faith.

\subsection{The Pious Emperor Constantius II}

Ephrem's praise for Constantius in a work written after 363 is surprising. ${ }^{58}$ Ephrem himself did not hesitate to write against the views of those he considered deviant. He authored a series of prose works with explicitly polemical content. ${ }^{59}$ One set of homilies and a lengthy cycle of hymns take a particularly strong stance against those who view God the Son as in some way subordinate to God the Father, socalled "Arianism." ${ }^{60}$ Ephrem saw himself rather as faithful to the Council of Nicaea of 325 whose creed declared that God the Son was "of the same being as the Father" and anathematised those that said the God the Son is "of another substance or be-

58 One other location in Ephrem's corpus has been cited as evidence for his positive perspective on Constantius: Ephrem the Syrian, Hymns on the Faith 87.21 (Beck, CSCO 154, Scr. Syri 73:271). On this passage, see Murray (cf. fn. 23) 66n2; Griffith (cf. fn. 16) 34; McVey (cf. fn. 6) 230n44. Following Wickes (cf. fn. 14) 21, 27, I would argue that this passage permits several contexts, and I have accordingly not considered it as evidence for Ephrem's views on Constantius here.

59 Ephrem the Syrian, Five Discourses addressed to Hypatius (Julian Joseph Overbeck, ed., S. Ephraemi Syri, Rabulae episcopi Edesseni, Balaei aliorumque opera selecta [Oxford, 1865], 21-58; C. W. Mitchell, ed. and trans., S. Ephraim's Prose Refutations of Mani, Marcion, and Bardaisan [London 1912-1921], 1:1-185); Discourse against Bardaisan's Discourse Entitled “Domnus” (Mitchell [cf. fn. 59], 2:1-49); Against False Teaching (ibid., 2:50-102); Two Discourses against Marcion (ibid., 2:103142); Discourse against Mani (ibid., 2:190-229).

60 A refutation of these viewpoints appears most strongly in Ephrem the Syrian, Homilies on the Faith (Edmund Beck, ed. and trans., Des heiligen Ephraem des Syrers Sermones de fide, CSCO 212213, Scr. Syri 88-89 [Leuven 1961]) and Hymns on the Faith (Beck, CSCO 154, Scr. Syri 73). On the content and contexts of these homilies and hymns, see Edmund Beck, Die Theologie des hl. Ephraem in seinen Hymnen über den Glauben, Studia Anselmiana 21 (Vatican City 1949); Edmund Beck, Ephraems Reden über den Glauben: Ihr theologischer Lehrgehalt und ihr geschichtlicher Rahmen, Studia Anselmiana 33 (Rome 1953); Wickes (cf. fn. 14) 19-43. 
ing" as God the Father. ${ }^{61}$ Ephrem does not use this language of "being" often in his corpus, but similar expressions of the equality of the Father and Son appear regularly. ${ }^{62}$ Constantius, on the other hand, summoned twin synods in Ariminum and Seleucia in Isauria in 359 to resolve ongoing disagreements over such language. ${ }^{63}$ Both affirmed a new declaration of faith, and a Synod in Constantinople in 360 promulgated the so-called Homoean Creed that directly opposed the language of "being" and "substance" used at Nicaea. ${ }^{64}$ Constantius sought to achieve unity through encouraging or enforcing adherence to this new creed, and he was sharply criticised by theologians who considered themselves faithful to Nicaea. ${ }^{65}$

Manolis Papoutsakis has offered one convincing argument for Ephrem's praise for Constantius in these hymns. He develops this argument at greatest length in a monograph on Syriac political thought in late antiquity. ${ }^{66}$ Here he contends against the assumption that Ephrem remained unaware that Constantius favoured nonNicene theology in spite of his own adherence to the council's theology. ${ }^{67}$ Instead, Papoutsakis draws attention to the careful interweaving of eschatological patterns from various biblical passages (Gn 49:10; Acts 12:23; 2 Thes 2:3-10) in Ephrem's positive portrayal of Constantius in Hymns against Julian 2.1. He concludes:

61 Symb. Nic. (325) (August Hahn and G. Ludwig Hahn, Bibliothek der Symbole und Glaubensregel,

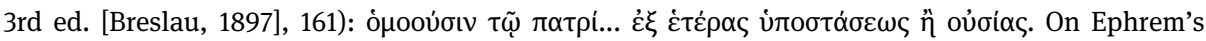
Trinitarian theology, see Beck (1949, cf. fn. 60); Beck (1953, cf. fn. 60); Edmund Beck, Ephräms Trinitätslehre im Bild von Sonne/Feuer, Licht und Wärme, CSCO 425, Subsidia 62 (Leuven 1981). For a short comparison with other fourth-century Trinitarian teachings, see Lewis Ayres, Nicaea and Its Legacy: An Approach to Fourth-Century Trinitarian Theology (Oxford 2010), 229-235.

62 See Wickes (cf. fn. 14) 37-39.

63 Diefenbach (cf. fn. 8) 83-94, argues against traditional historiography that an empire-wide confession was an instrument for unity that Constantius first used with these councils. This was not a primary means of his engagement in ecclesiastical affairs.

64 Homoean Creed (Hahn and Hahn [cf. fn. 61] 209): 'As for the term 'ovंбí,' which was rather simplistically taken up by the fathers and brought in a stumbling-block for the people as something unknown, for the scriptures do not include this [term], it was resolved that it be removed and no mention [of it] be made in the future at all, because the divine scriptures also did not make mention in any way of the 'ovंбia' of the Father and of the Son. It is also not permissible for the term

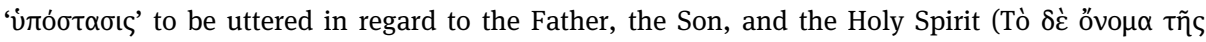

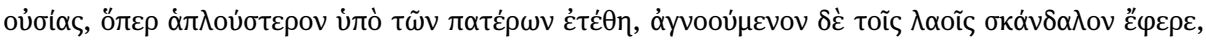

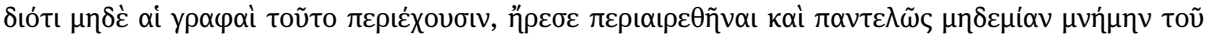

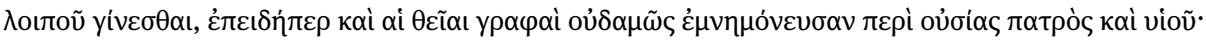

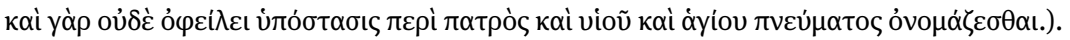

65 On Constantius's role in these synods, see Brennecke (cf. fn. 7) 5-56; Barnes (cf. fn. 8) 144-151. 66 In an earlier article, Papoutsakis noted that Ephrem modelled his account of Julian's death on the death of Herod Agrippa I as described in Acts 12:23: Papoutsakis (cf. fn. 20) 45. He refers here to Ephrem the Syrian, Hymns against Julian 4.3 (Beck, CSCO 174, Scr. Syri 78:85).

67 Papoutsakis (cf. fn. 4) 88. For this view, he points especially to Murray (cf. fn. 23) 111, 244-245. 
Ephrem's representation of Julian as an Antichrist figure is based on the presupposition that the Apostate interrupted the yubbālā ('succession'), or šāqa ('continuous line'), of the Constantinids, who mirrored the Judahite dynasty which had been broken only by Herod. It would have been impossible for such a line of kings to be drawn - and, thus, for Ephrem's representation of Julian to be sustained - without an orthodox Constantius. ${ }^{68}$

Papoutsakis's detailed analysis of the eschatological framework of these hymns should call into question any assumption about Ephrem's ignorance of Constantius's support of creeds opposed to the Nicene Creed. It further suggests that analyses of Ephrem's carefully chosen language and analogies will help explain his intentional representation of Constantius as a faithful ruler.

Papoutsakis's attention to the eschatological framework employed by Ephrem in these hymns can also explain Ephrem's praise for Constantius's piety in part. Ephrem's comparison of Constantius with the king of Nineveh provides some evidence that he praised the content of Constantius's faith directly. The interpretive crux rests on the proper understanding of the term "sackcloth." As noted above, this term is contrasted with Julian's "blasphemy" and thus seems to refer to Constantius's reverence. The eschatological framework offers a plausible argument for Ephrem's decision to portray Constantius's faith in a positive light. Constantius had to be a faithful ruler so that Julian's reign would break a line of faithful rulers. On this view, Ephrem glossed over the theological differences in deference to his eschatological argument.

Yet both the vine symbolism and pastoral imagery employed by Ephrem invite a second explanation for Ephrem's praise of Constantius. First, as detailed above, Ephrem uses language related to the vine and to shepherds to draw a contrast between Constantius and Julian in fulfilling their duties to ward off enemies and to provide peace for the Christian community. The particular type of Christianity to which rulers adhered does not affect Ephrem's evaluation of the execution of their duties. The historical circumstances in which Ephrem wrote offer one compelling explanation for Ephrem's positive representation of Constantius. They do not represent the entirety of his political thought throughout his career but rather provide a snapshot of his deep reflections on Christian rulership in the aftermath of the loss of the city of Nisibis.

Second, despite Constantius's theological views, his reign and conduct as an emperor produced conditions that allowed the church in Nisibis to survive. Ephrem's emphasis on the protection that emperors should provide Christian com-

68 Papoutsakis (cf. fn. 4) 88 (see also 112, 112n123, 120, 192). He also draws attention to the similar comparison between Herod and Julian in Gr. Naz., or. 4.68 (Bernardi [cf. fn. 47] 178): "after [the

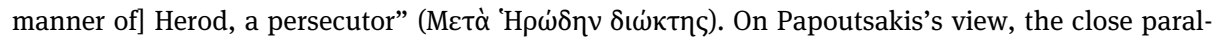
lels in the two works on this theme suggest that Ephrem was familiar with this passage in Gregory (Papoutsakis [cf. fn. 4] 120-137, 193). 
munities offers a partial explanation of his reticence to comment on Constantius's support for non-Nicene theology. Ephrem appears in this corpus as an author writing to address the threats his community faced during a difficult change of events. In his third Hymn against Julian, as Papoutsakis has argued, Ephrem does respond directly to a development in political thought, namely, the deification of Julian by his adherents. ${ }^{69}$ But his employment of vine symbolism and pastoral imagery offers insight not into programmatic Christian political thought but rather into the perspective of an individual author writing on individual emperors based on the threats faced by his community. It will be useful, therefore, to turn to texts that offer more clarity to understand the phenomenon of praising emperors with whom one disagrees.

\section{Jacob of Serugh: Letter to Paul of Edessa}

Jacob of Serugh lived from around 451 to $520 / 1$ in the region of Mesopotamia. ${ }^{70} \mathrm{He}$ studied at the school of Edessa before its relocation to Nisibis. ${ }^{71}$ His ecclesiastical identity remained a source of debate throughout the Middle Ages and even until the late twentieth century. It is now quite clear that he adhered to the miaphysite, that is, anti-Chalcedonian or non-Chalcedonian point of view, even if he appears moderate compared to some of his contemporaries. ${ }^{72} \mathrm{He}$ became known even in his lifetime for the numerous homilies he preached and that later circulated in manuscripts. ${ }^{73}$ His extant homiletical corpus comprises the third largest single-author

69 Papoutsakis (cf. fn. 17).

70 For an overview of Jacob's life and works, see Sebastian P. Brock, "Ya'qub of Serugh," in Gorgias Encyclopedic Dictionary of the Syriac Heritage, ed. Sebastian P. Brock et al. (Piscataway, NJ 2011), 433-434.

71 Jacob himself notes that he studied at the school in Jacob of Serugh, Letters 14 (Olinder, Epistulae, CSCO 110, Scr. Syri 57:58-59). On the school, see especially Adam H. Becker, Fear of God and the Beginning of Wisdom: The School of Nisibis and Christian Scholastic Culture in Late Antique Mesopotamia, Divinations: Rereading Late Ancient Religion (Philadelphia 2006); Adam H. Becker, trans., Sources for the History of the School of Nisibis, Translated Texts for Historians 50 (Liverpool 2008).

72 On the history of scholarship regarding his Christology, see Philip Michael Forness, "Cultural Exchange and Scholarship on Eastern Christianity: An Early Modern Debate over Jacob of Serugh's Christology," Journal of Eastern Christian Studies 70, no. 3-4 (2018): 257-284; Philip Michael Forness, "Manuscript Discoveries and Debates over Orthodoxy in Early Christian Studies: The Case of the Syriac Poet-Theologian Jacob of Serugh," Harvard Theological Review, forthcoming.

73 As evidenced in a chronicle written not long after 506: Pseudo-Joshua the Stylite, Chronicle 54 (Jean-Baptiste Chabot, ed., Chronicon anonymum Pseudo-Dionysianum vulgo dictum, trans. JeanBaptiste Chabot and Robert Hespel, CSCO 91, 104, 121, 507, Scr. Syri 43, 53, 66, 213 [Leuven 19271989], CSCO 91, Scr. Syri 43:280-281; J. W. Watt and Frank R. Trombley, trans., The Chronicle of 
collection of homilies from late antiquity. ${ }^{74}$ His epistolary corpus has been less explored. It consists of forty-two letters that he wrote to various public officials, religious leaders, and private individuals. ${ }^{75}$

Near the end of his life, the fate of the miaphysite or non-Chalcedonian community took a turn for the worse. Emperor Anastasius I had been relatively sympathetic to the miaphysite community and supported the Emperor Zeno's (r. 474-491) Henotikon as a compromise between pro- and anti-Chalcedonian parties, despite its limited success. The miaphysites gained strength during Anastasius's reign. But Justin's ascension to the imperial throne in 518 presented a crisis for miaphysite leaders. ${ }^{76}$ Jacob, now a bishop in the city of Serugh in the region of Batnae in Mesopotamia, experienced the problems that Justin's rise to power and policies on Christology brought for the miaphysite community in his local setting. Two of his letters offer evidence for the reaction of the miaphysite communities to Justin's policies: Letter 32 to bishop Paul of Edessa (r. 510-522) and Letter 35 to the military comes Bessas (d. after 554). I will first describe the content of the letters to explicate the context further. ${ }^{77}$ I will then analyse Jacob's surprising praise for Justin and even the content of his faith found within one of these letters.

Pseudo-Joshua the Stylite, Translated Texts for Historians 32 [Liverpool 2000], 63-64). On the date of the Chronicle, see Watt and Trombley (cf. fn. 73) xxviii-xxix.

74 The corpora of Augustine of Hippo and John Chrysostom contain more homilies than Jacob's. The most recent listing of Jacob's homilies appears in Roger-Youssef Akhrass and Imad Syryany, eds., 160 Unpublished Homilies of Jacob of Serugh (Damascus 2017), 1:xiv-xxiii. On his wider literary output, see Sebastian P. Brock, "Jacob of Serugh: A Select Bibliographical Guide," in Jacob of Serugh and His Times: Studies in Sixth-Century Syriac Christianity, ed. George Anton Kiraz, Gorgias Eastern Christian Studies 8 (Piscataway, NJ 2008), 219-244.

75 Jacob of Serugh, Letters (Olinder, CSCO 110, Scr. Syri 57). On the various modern translations of these letters, see fn. 7 above.

76 For an overview of the theological developments during Justin's reign, see Vasiliev (cf. fn. 5) 132-253; Grillmeier (cf. fn. 11) 318-337; Speigl (cf. fn. 11); Brian Croke (cf. fn. 11) 26-33, 35-39, 5253; Volker L. Menze, Justinian and the Making of the Syriac Orthodox Church, Oxford Early Christian Studies (Oxford 2008a), 16-57. Especially pertinent for this study is Volker L. Menze, "Jacob of Sarug, John of Tella and Paul of Edessa: Ecclesiastical Politics in Osrhoene 519-522," in Malphono w-Rabo d-Malphone: Studies in Honor of Sebastian P. Brock, ed. George Anton Kiraz, Gorgias Eastern Christian Studies 3 (Piscataway, NJ 2008b), 421-438.

77 Taeke Jansma, "Encore le credo de Jacques de Saroug: Nouvelle recherches sur l'argument historique concernant son orthodoxie," L'Orient Syrien 10 (1965): 500-501, drew attention to the relationship between these two letters. 


\subsection{The Emperor Justin I and the Siege of Edessa}

At least two of Jacob of Serugh's letters address the immediate aftermath of Justin's growing opposition to miaphysite churches in the early years of his reign. ${ }^{78}$ Aside from the Emperor Justin, two additional figures prove essential to understanding the rather complicated context in which Jacob wrote these letters. First, Paul of Edessa became bishop in 510 and remained in this position throughout the reign of Anastasius and the episcopacy of Severus of Antioch (r. 512-518). ${ }^{79}$ In short, he was a bishop through a relatively peaceful time for the anti-Chalcedonian or miaphysite movement. The second figure is Pope Hormisdas (r. 514-523) who rose to the papacy in 514 and tried throughout his career to bring reconciliation between Rome and Constantinople. ${ }^{80}$ He authored a pro-Chalcedonian text entitled the Formula of Faith sometime around the year $515 . .^{81}$

Justin tried early in his reign to bring an end to the so-called Acacian schism that had divided Rome and Constantinople since the late fifth century. ${ }^{82}$ On March 28th, 519, he adopted Hormisdas's pro-Chalcedonian Formula of Faith as a basis for reconciliation. He demanded that bishops sign on to this document to prove their orthodoxy. ${ }^{83}$ In November 519, he had a military general lay siege to Edessa, as the bishop of this city Paul had refused to sign this text. ${ }^{84}$ Paul refused again and was

78 The analysis of these letters draws on a closer examination of their Christology in Philip Michael Forness, Preaching Christology in the Roman Near East: A Study of Jacob of Serugh, Oxford Early Christian Studies (Oxford 2018), 99-115.

79 On Paul of Edessa, see Ernst Honigmann, Évêques et évêchés monophysites d'Asie antérieure au $V I^{e}$ siècle, CSCO 127, Subsidia 2 (Leuven 1951), 49-50; Jansma (cf. fn. 77) 193-236; Menze (2008b, cf. fn. 76) 423-427.

80 On Hormisdas, see Erich Caspar, Geschichte des Papsttums: Von den Anfängen bis zur Höhe der Weltherrschaft (Tübingen 1930-1933), 2:129-183.

81 Hormisdas, Formula of Faith (Walter Haacke, Die Glaubensformel des Papstes Hormisdas im Acacianischen Schisma, Analecta Gregoriana 20 [Rome 1939], 10-14).

82 On the background and history of this schism, see C. Capizzi, "Sul fallimento di un negozio di pace ecclesiastica fra il papa Ormisda e l'imperatore Anastasio I," Storia critica 17 (1980): 23-54; Jan-Markus Kötter, Zwischen Kaisern und Aposteln: Das Akakianische Schisma (484-519) als kirchlicher Ordnungskonflikt der Spätantike, Altertumswissenschaften 2 (Stuttgart 2013).

83 On the resolution of this conflict and its consequences for bishops, see Caspar, Geschichte des Papsttums, 2:149-181; Vasiliev (cf. fn. 5) 161-190; Grillmeier (cf. fn. 11) 322-327; Menze (2008a, cf. fn. 76) 32-34.

84 On the events of November and December 519, see Menze (2008b, cf. fn. 76) 424-427. Nestor Kavvadas, Ephraem der Syrer und Basilios der Grosse, Justinian und Edessa: Die Begegnung griechischer und syrischer Traditionsautorität in der Ephraemvita und der miaphysitisch-chalkedonische Konflikt (Leiden 2018), 134-147, highlights the parallels with these events found in the sixth-century Life of Ephrem that was written in Edessa. The attack on Edessa appears in five Syriac chronicles: Chronicle of Edessa 88-95 (Ignazio Guidi, ed. and trans., Chronica minora, pars I, CSCO 1-2, Scr. Syri 1-2 [Paris 1903], CSCO 1, Scr. Syri 1:10-11); Chronicle to the Year 819 (Jean-Baptiste Chabot, ed., Anonymi auctoris Chronicon ad annum Christi 1234 pertinens, CSCO 81, Scr. Syri 36 [Paris 1920], 8); 
exiled. Forty days later, in December 519, Justin demanded that Paul be allowed to return to the city. ${ }^{85}$ Jacob of Serugh wrote letters to Paul of Edessa and to the military leader Bessas shortly thereafter. Justin had bartered a deal with Rome that led him to promote adherence to Chalcedon once again.

Jacob's letter to Paul of Edessa seems to come directly after Paul has been welcomed back into the city. ${ }^{86}$ This letter begins with parallels between the sojourn of the biblical Joseph in Egypt and Paul's exile from Edessa. ${ }^{87}$ Jacob then turns to Paul's situation itself: "But to you, O prince of God, God has truly shown favour, so that you might rise to the step of the confessors and be persecuted by those who worship a human." 88 The title of "confessor" that Jacob assigns to Paul here is the technical term in Syriac - the same as known in other languages - for those who were persecuted but not killed for their faith. ${ }^{89}$ Paul, on Jacob's view, had done rightly in opposing the Formula of Faith and the policies of Justin.

Jacob wrote a second letter in the aftermath of the military general Patricius's invasion of Edessa to a comes named Bessas, who was a military leader in the city of Edessa at the time that Patricius tried to pressure Paul of Edessa to sign the Formula

Chronicle to the Year 846 (E. W. Brooks, ed., Chronica minora, pars II, trans. Jean-Baptiste Chabot, CSCO 3-4, Scr. Syri 3-4 [Paris 1904], CSCO 3, Scr. Syri 3:228-229); Chronicle of Zuqnin (Chabot [1927-1989, cf fn. 73] CSCO 104, Scr. Syri 53:24-25); Michael the Syrian, Chronicle 9.14 (JeanBaptiste Chabot, ed. and trans., Chronique de Michel le Syrien [Paris 1889-1909], 4:267-268). The account in the Chronicle of Zuqnin derives from the second part of the Ecclesiastical History of John of Ephesus. On the relationship of these works, see Jan J. van Ginkel, "John of Ephesus: A Monophysite Historian in Sixth-Century Byzantium” (Ph.D. diss., Rijksuniversiteit Groningen, 1995), 54-57; Amir Harrak, trans., The Chronicle of Zuqnin, Parts III and IV: A.D. 488-775, Mediaeval Sources in Translation 36 (Toronto 1999) 18-19. As Ginkel explains, portions of the Chronicle to the Year 846 and Michael the Syrian's Chronicle also draw on John of Ephesus's Ecclesiastical History. In this regard, it is important to note that Michael the Syrian cites John of Ephesus as the source for chapter 9.13 that appears parallel to 9.14 in the Chronicle (Chabot [1889-1909, cf. fn. 84] 4:266).

85 As discussed below, Paul's return to the city appears in Jacob of Serugh's letter as well as in the Chronicle of Edessa 88 (Guidi, Chronica minora, pars I, CSCO 1, Scr. Syri 1:10).

86 Jacob of Serugh, Letters 32 (Olinder, CSCO 110, Scr. Syri 57:244-245): "Because 'the heart of the king is in the hands of the Lord' [Prv 21:1], God also made him worthy so that the truth might appear and his faith might be known to the whole world. He immediately returned you to your throne with his swift command" (

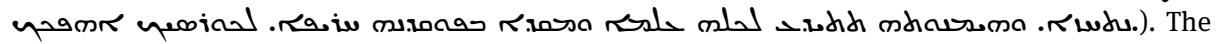
word דתم. should read as suggested already in Gunnar Olinder, The Letters of Jacob of Sarug: Comments on an Edition, Lunds Universitets Årsskrift, n.f., avd. 1, 34.1 (Lund 1939), 115. See the discussion of this quotation below.

87 Jacob of Serugh, Letters 32 (Olinder, CSCO 110, Scr. Syri 57:241-243).

88 Jacob of Serugh, Letters 32 (Olinder, CSCO 110, Scr. Syri 57:243):

لע .

89 On the Syriac word rus, see R. Payne Smith, ed., Thesaurus syriacus (Oxford, 1879), 1:1551.

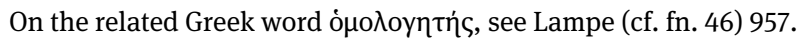


of Faith. This Bessas is a well-known military leader mentioned by several sixthcentury Greek and Latin historians. ${ }^{90}$ Throughout the letter, Jacob praises Bessas for his right belief. He calls him a "faithful believer," states that the city has been exalted through his faith, ${ }^{92}$ recognises the sufferings he has endured for the sake of his faith, ${ }^{93}$ compares him to the ruler Abgar (who is credited with introducing Christianity to Edessa), and claims that he has been faithful to his bishop Paul of Edessa. ${ }^{94}$ This letter also features a very pointed exposition of Christology. Jacob describes a miaphysite Christology against a Chalcedonian perspective. ${ }^{95}$ He draws on the language of Zeno's Henotikon and its miaphysite interpretation to praise Bessas for holding true to the faith. The faith that Jacob praised in Bessas was not generic but was a specifically miaphysite understanding of Christology.

These two letters form a picture of Jacob's view of Justin's policies against the miaphysite community. Jacob praised a bishop who refused to sign the Formula of

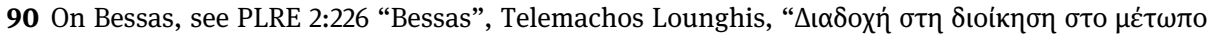

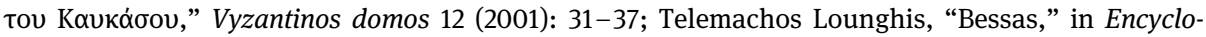
paedic Prosopographical Lexicon of Byzantine History and Civilization, ed. Alexios G. Savvides, Benjamin Hendrickx, and Thekla Sansaridou-Hendrickx, vol. 2 (Turnhout 2008), 112-113.

91 Jacob of Serugh, Letters 35 (Olinder, CSCO 110, Scr. Syri 57:257): "To the great, victorious, and faithful believer, Mar Bessas, the comes, Jacob the worshipper of your greatness in our Lord: Peace"

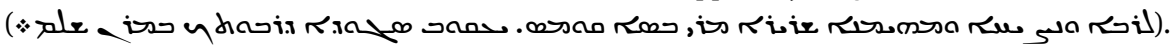

92 Jacob of Serugh, Letters 35 (Olinder, CSCO 110, Scr. Syri 57:258): "Your city has been exalted through you" (udu.

93 Jacob of Serugh, Letters 35 (Olinder, CSCO 110, Scr. Syri 57:258): "Your mind rejoiced in our Lord that he made you worthy to suffer for his sake and to be plundered and disgraced, because you determined in your soul that if the one who is not needy suffers when he does not need to, how much more is it right that we, who are needy, wretched, and weak, suffer for his sake in those things

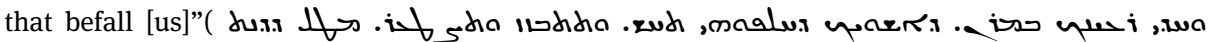

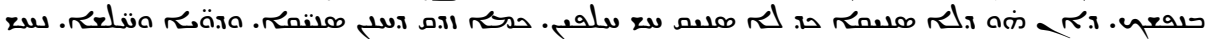

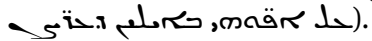

94 Jacob of Serugh, Letters 35 (Olinder, CSCO 110, Scr. Syri 57:260): "It is good for you, O faithful Christian that you have guarded this true faith in your soul. You have become a good heir to Abgar the Parthian. Just as you inherited his city, so its faith you have also inherited. You have risen as a powerful one and warrior. You have demonstrated the truth of your faith to Mar Paul, the shepherd

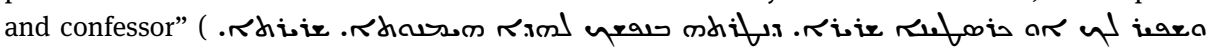

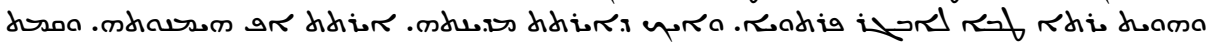
r.

95 For one example, see Jacob of Serugh, Letters 35 (Olinder, CSCO 110, Scr. Syri 57:259): "Of this same only-begotten are all the things that he encountered on the way of his economy: of him are the miraculous feats that he performed and of him are the sufferings that he endured; of him is the

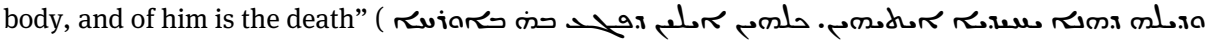

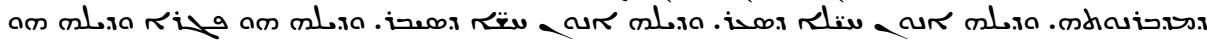
rhos). The language of miracles and sufferings as featured in the quotation appears in Zeno's Henotikon in response to the Tome of Pope Leo, which was itself accepted at the Council of Chalcedon. This language was adopted by miaphysites in the early sixth century. The pairing of miracles and sufferings is explored at greater length in Forness (cf. fn. 78). 
Faith and went into exile as a result. He also commended a military leader who suffered for his support of the miaphysite community. With the letter to Bessas, we also receive further clarification on Jacob's partisan viewpoint on this event. He remained an advocate of miaphysite Christology in contrast to Justin and those that enforced his policies. This emphasis on correct doctrinal belief found in both letters - and especially emphasised in Letter 35 to the comes Bessas - forms a background to Jacob's surprising praise for Justin.

\subsection{Praise for Justin I in the Letter to Paul of Edessa}

In his letter to Paul of Edessa, Jacob praises Justin as a faithful ruler and extols the content of his faith. ${ }^{96}$ The letter, as noted earlier, features an extended description of the biblical Joseph's trials in Egypt and God's use of these trials to effect good. On Jacob of Serugh's view, this narrative serves as a useful point of comparison to the persecution that Paul of Edessa has faced. Jacob notes that people started to question why God allowed Paul to be persecuted when he was indeed a good and faithful bishop. Jacob views the situation after Paul has already been restored to his episcopacy by Justin and offers a theological explanation in two parts.

In the first part, he describes the emperor's actions in returning Paul to his throne. An extended quotation from this section of the letter reveals Jacob's interpretation of the emperor's actions:

\footnotetext{
The emperor, faithful and worthy of victory, learned the things that had been done to you, was stirred and disturbed, and feared that they might befall him. Because "the heart of the king is in the hands of the Lord" [Prov 21:1], God also made him worthy so that the truth might appear and his faith might be known to the whole world. He immediately returned you to your throne with his swift command. He reproached and scorned your enemies. He made known to everyone that he [by] his will excommunicates those who through the tyranny of others disgraced the baptistery and persecuted you. ${ }^{97}$
}

96 This letter receives some attention in Vasiliev (cf. fn. 5) 234; Friedrich Winkelmann, "Der Laós und die kirchlichen Kontroversen im frühen Byzanz," in Volk und Herrschaft im frühen Byzanz: Methodische und quellenkritische Probleme, ed. Friedrich Winkelmann, Berliner byzantinistische Arbeiten 58 (Berlin 1991), 150-151.

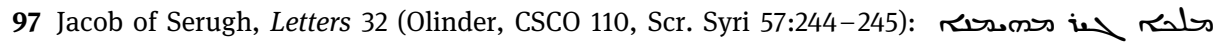
ardidir mids

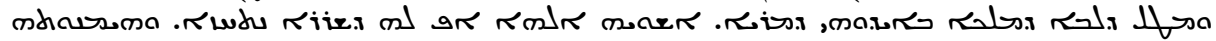

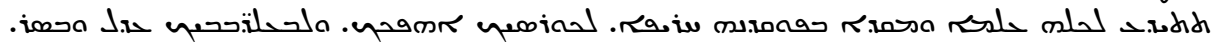

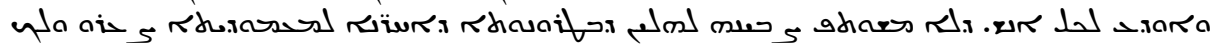

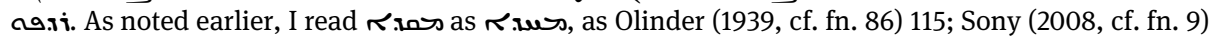
399. 
On Jacob's view, Justin was a pawn that God used to communicate the true faith. Justin acted as God's agent in returning Paul to his throne, and through him God rebuked those who had opposed the faithful bishop Paul. This is the tenor of the quotation as a whole. Yet, already we see a sign that something deeper may underlie Justin's actions. Jacob's quotation of Proverbs 21:1 - "the heart of the king is in the hands of the Lord" - serves as an indication of Jacob's perspective on the emperor's faith. This quotation appears in the panegyrical tradition to communicate that the emperor is already in God's hands and to encourage him to act in a way that corresponds to this reality. ${ }^{98}$

In the second section of praise for the emperor, Jacob becomes more specific about the content of Justin's faith. First, he compares Justin's faith to that of emperors famous for their faithfulness: "For I am convinced as follows: God did not accomplish this salvation for your sake alone, but rather for the sake of the faithful emperor so that the beauty of his truth might be seen and his faith - which is full of beauty and peace - might be proclaimed as that of the blessed Constantine and that of the faithful Abgar." "Jacob states that Justin has the same faith as Abgar of Edessa who is seen as the inaugurator of the Christian faith in the city of Edessa. ${ }^{100} \mathrm{He}$ is said to have the same faith as Constantine the Great, whom Jacob praises elsewhere for his role in organizing the Council of Nicaea. ${ }^{101}$

Jacob continues describing Justin's faith by focusing on the image of his crown that features the cross of Christ. He writes:

For his faith is not less than that of the disciples of the cross. Since if he had not affirmed that the one who hung on the cross is God, then he would not also have carried his cross on the height of his diadem. If the cross were of a [mere] person, as those who seek to lead the emper-

98 This appears in three of Themistius's orations: Them., or. 7.89d (Wilhelm Dindorf, ed., Themistii Orationes [Leipzig, 1832], 107); 11.147c (ibid., 175); 19.229a (ibid., 278). On Themistios's use of this passage, see G. Downey, “Allusions to Christianity in Themistius' Orations," StP 5 (1962): 482-484; Gilbert Dagron, L'Empire romain d'Orient au IVe siècle et les traditions politiques de l'hellénisme: Le témoignage de Thémistios, TM 3 (Paris: De Boccard, 1968), 150-153. I am grateful to Hartmut Leppin and Simone Mehr for drawing my attention to this tradition.

99 Jacob of Serugh, Letters 32 (Olinder, CSCO 110, Scr. Syri 57:245):

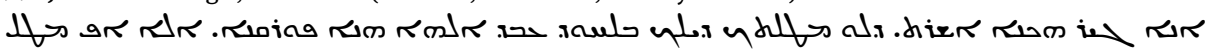

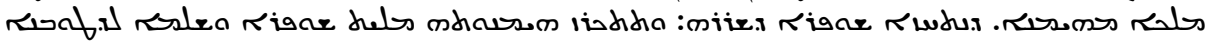

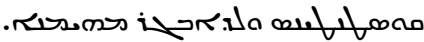

100 Jacob frames Abgar as a mark of orthodoxy in two other letters to leaders in Edessa. See Jacob of Serugh, Letters 20 (Olinder, CSCO 110, Scr. Syri 57:130, 132-134); 32 (Olinder, CSCO 110, Scr. Syri 57:245).

101 See especially Jacob of Serugh, Homily on the Council of Nicaea (Paul Bedjan, ed., S. Martyrii qui et Sahdona quae supersunt omnia [Paris 1902], 842-865). Another homily discusses the long process by which Constantine came to support Christianity, see Jacob of Serugh, Homily on the Baptism of Constantine (Paul Bedjan and Sebastian P. Brock, eds., Homilies of Mar Jacob of Sarug [Piscataway, NJ 2006], 6:298-323). 
or astray and mock God say, the emperor would not have taken it upon himself to wear the cross of a person above his diadem. ${ }^{102}$

Jacob's reference to an imperial diadem that has a cross remains unclear. While the cross became a known feature on the imperial crown later, there are no remains or other literary descriptions of the imperial crown with a cross on it from late antiquity. ${ }^{103}$ But Roman coinage as early as 353 features emperors wearing a diadem with a cross on top, ${ }^{104}$ and Jacob could have encountered coins of Justin with such a crown. ${ }^{105}$ Jacob emphasises that Justin's wearing of the cross is a sign that he con-

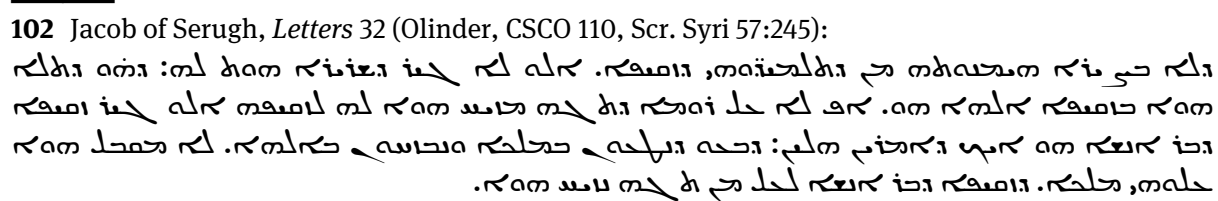
103 On the crowns of Roman Emperors, see especially A. Mau, "Diadema," in RE 5:303-305; Andreas Alföldi, "Die Ausgestaltung des monarchischen Zeremoniells am römischen Kaiserhofe," $\operatorname{MDAI}(\mathrm{R}) 49$ (1934): 17-18; Andreas Alföldi, “Insignien und Tracht der römischen Kaiser,” MDAI(R) 50 (1935): 10-12, 38-41, 51-57, 122-124, 139-150; Karl Baus, Der Kranz in Antike und Christentum: Eine religionsgeschichtliche Untersuchung mit besonderer Berücksichtigung Tertullians, Theophaneia: Beiträge zur Religions- und Kirchengeschichte des Altertums 2 (Bonn 1940); Klaus Wessel, Elisabeth Piltz, and Corina Nicolescu, "Insignien," in RbK 3:373-398; Michael McCormick, "Crown," in ODB 1:554; Erich Dinkler and Erika Dinkler-von Schubert, "Kreuz I," in RbK 5:47; Aimilia Yeroulanou, ed., Diatrita: Gold Pierced-Work Jewellery from the 3rd to the 7th Century (Athens 1999), 41-43, 216 (no. 68-69); Paul Corby Finney, “Diadem," in The Eerdmans Encyclopedia of Early Christian Art and Archaeology, ed. Paul Corby Finney, vol. 1 (Grand Rapids, MI 2017), 419.

104 Philipp Lederer, "Beiträge zur römischen Münzkunde: V. Kaiserbildnisse mit Kreuzdiadem," Deutsche Münzblätter 11, no. 54 (1934): 213-220, 242-245, 267-270; Michail A. Bojcov (Boytsov), "Der Heilige Kranz und der Heilige Pferdezaum des Kaisers Konstantin und des Bischofs Ambrosius," FMSt 42, no. 1 (2010): 51-53. Baus (cf. fn. 103) 201, mentions the introduction of the symbol of the cross to the imperial crown. But he only cites Alföldi (1935, cf. fn. 103) 150, 150n1, who in turn points back to Lederer (cf. fn. 104). Baus (cf. fn. 103) discusses several literary sources and artistic depictions of crowns that encircle a cross. Yet there is no direct connection between these crowns and the crown worn by the emperor. Josef Engemann, "Das Kreuz auf spätantiken Kopfbedeckungen (Cuculla - Diadem - Maphorion)," in Theologia crucis - signum crucis: Festschrift für Erich Dinkler zum 70. Geburtstag, ed. Carl Andresen and Gunter Klein (Tubingen 1979), 143-149, discusses the apotropaic function of nails in the diadem that seem related to the emergence of coins with imperial diadems with the cross. Bojcov (Boytsov) (cf. fn. 104) 42-47, explores Engemann's suggestion that two nails could have been arranged in a cross on the crown. Bojcov (Boytsov) (cf. fn. 104) 55-57, also identifies writings by John Chrysostom and Augustine of Hippo that similarly suggest that the emperor's crown featured a depiction of the cross.

105 For coins that feature a cross above Justin's head bordering on the crown, see Dumbarton Oaks Collection 10, 29a.1, 31, 35 (Alfred Raymond Bellinger, Philip Grierson, and Michael F. Hendy, Catalogue of the Byzantine Coins in the Dumbarton Oaks Collection and in the Whittemore Collection [Washington, D.C. 1966-1999], 1:41, 48-50, Plate IX); Hahn 112 $12^{2}, 13^{2}, 35^{3}, 38^{3}, 39^{2}$, 42 (Wolfgang Hahn, Moneta Imperii Byzantini: Rekonstruktion des Prägeaufbaues auf synoptisch-tabellarischer Grundlage, Österreichische Akademie der Wissenschaften, Philosophisch-Historische Klasse, 
firms that the one who is crucified is God. Here his language of "the one who hung on the cross is God" seems to be a reference to the debate over the addition of the phrase "who was crucified for us" to the liturgical Trishagion. ${ }^{106}$ Advocates of miaphysite Christology supported the inclusion of this phrase in the Trishagion. The allusion to the Trishagion here assumes a specific type of Christological belief. Justin is praised by Jacob as though he were an adherent to a miaphysite view of Christology.

Jacob praises Justin both for his action in restoring Paul of Edessa to his episcopal see and for his assumed adherence to miaphysite Christology. It may well be the case that Justin sought a more peaceful way of dealing with detractors from his strong stance on adherence to the Formula of Faith of Pope Hormisdas. Paul of Edessa's return forms one strong indication that he at least varied his approach based on popular response. But there is no indication that he ever changed his official perspective on adherence to the formula or that he ever supported a miaphysite cause. Jacob's praise not only for his action but also for his right belief stands out as an anomaly in comparison to his hard stance on miaphysite theology that he takes in both this letter and his letter to Bessas.

\subsection{The Pious Emperor Justin I}

How can Jacob's support for Justin be explained? Did Jacob really consider him to be a supporter of miaphysite Christology? At one extreme, one could interpret Jacob's letter literally. He held that Justin's actions were good indications of his beliefs. Justin, on his view, would not act contrary to his own beliefs. On the other hand, this letter may have been strategically composed with the hope that its wider audi-

Denkschriften 109, 119, 148; Veröffentlichungen der numismatischen Kommision 1, 4, 10 [Vienna 1973-1981], 1:40-41 [Textteil]; 1:6, 8-9 [Tafelteil]); and Sear 62, 68, 84, 91, 100, 104 (David R Sear, Byzantine Coins and Their Values, 2nd rev. [London 1987], 45-46, 48-50);

106 For overviews of this debate, see Edith Klum-Böhmer, Das Trishagion als Versöhnungsformel der Christenheit: Kontroverstheologie im V. u. VI. Jh. (Munich 1979); Sebastian P. Brock, "The ThriceHoly Hymn in the Liturgy," Sobornost 7, no. 2 (1985): 24-34; Alois Grillmeier, Christ in Christian Tradition, vol. 2, From the Council of Chalcedon (451) to Gregory the Great (590-604), part 2, The Church of Constantinople in the Sixth Century, trans. John Cawte and Pauline Allen (London 1995), 254-262; Dana Iuliana Viezure, "Verbum Crucis, Virtus Dei: A Study of Theopaschism from the Council of Chalcedon (451) to the Age of Justinian” (Ph.D. diss., University of Toronto, 2009), 121141; Luise Abramowski, "From the Controversy on 'Unus ex Trinitate passus est': The Protest of Habib against Philoxenus' Epistula dogmatica to the Monks," in Christ in Christian Tradition, vol. 2, From the Council of Chalcedon (451) to Gregory the Great (590-604), part 3, The Churches of Jerusalem and Antioch from 451 to 600, ed. Theresia Hainthaler, trans. Marianne Ehrhardt (Oxford 2013), 545-620; David Allen Michelson, The Practical Christology of Philoxenos of Mabbug, Oxford Early Christian Studies (Oxford 2014), 155-159. 
ence - certainly wider than Paul of Edessa - would remain faithful to their Christological beliefs. The letter may even have had the Edessene Christian community in mind in encouraging them not to change their views on Christology.

In either case, Jacob of Serugh's letter aims to support the miaphysite community of Edessa that had just seen the potential consequences of living under a ruler whose policies supported a different expression of Christology. Justin's order to allow Paul of Edessa to return to the city prevented further civil unrest in a part of the empire in which many miaphysite communities lived. Regardless of his motivations and his actual Christological beliefs, he preserved the community and for this reason he received praise. Jacob, as Ephrem before him, praises emperors for creating the conditions that allow their communities to exist and prosper. Their words of praise belie an expectation of emperors to maintain peace under which Christian communities can flourish. For this, they receive praise or blame.

\section{Conclusion}

Despite the great differences in genre, Ephrem's hymns and Jacob's letter attest to a wider phenomenon of praising emperors with whom one disagrees theologically. ${ }^{107}$ Gregory of Nazianzus writes of Constantius: "Never did a burning desire grasp someone for a certain act in such a way as [Constantius] for the strengthening of Christians and their advancement to the height of both glory and power." ${ }^{108}$ The three major fifth-century church historians take different approaches to Constantius. While Socrates of Constantinople (c. 380-after 439) emphasises Constantius's support for "Arianism" and finds little to praise in his ecclesiastical engagement, Sozomen of Constantinople (fl. early fifth century) claims that Constantius had the same faith as his father - it was merely a matter of language - and highlights his support for the church. Most significantly for this study, Theodoret of Cyrrhus excuses Constantius's faith and highlights his promotion of the church in contrast to Julian. ${ }^{109}$ Theodoret, who wrote from the province of Euphratensis, just one province away from that of Edessa and Serugh, shared the same views as Ephrem. The sixthcentury Syriac polemical writing, known as the Julian Romance, seems familiar with

107 The two sources noted here are mentioned in Papoutsakis (cf. fn. 4) 72, 88n53.

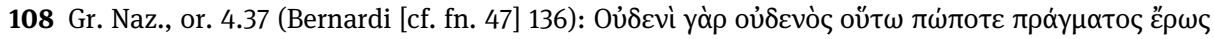

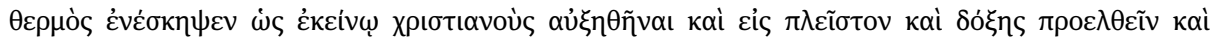

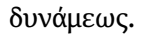

109 On the views of these three church historians on Constantius, see Hartmut Leppin, Von Constantin dem Großen zu Theodosius II.: Das christliche Kaisertum bei den Kirchenhistorikern Socrates, Sozomenus und Theodoret, Hypomnemata: Untersuchungen zur Antike und zu ihrem Nachleben 110 (Göttingen 1996), 60-66. 
Ephrem's works. ${ }^{110}$ The final title to one of the sections of the work erases all differences between Constantine's faith and that of his sons, speaking of "the faith of Constantine and of his three sons." 111 Investigations of such statements may reveal the motivations of these authors in glossing over theological differences in their representation of rulers.

The historical circumstances in which Ephrem and Jacob wrote offer one explanation for their positive portrayal of Constantius and Julian. In Ephrem's time, the Roman Empire had ceded Nisibis to the Persian Empire, while, in Jacob's, the enactment of new policies against miaphysite communities led to the persecution of the bishop and citizens of Edessa. Both authors regularly criticised their theological opponents. Ephrem wrote treatises against those he deemed heretics and wove antiArian rhetoric into his hymns. Jacob similarly supported miaphysite Christology throughout his career, and he expressed this especially clearly in his letters to Paul of Edessa and the military general Bessas. The clarity in both authors' works regarding doctrinal matters makes their praise for emperors who did not share their theological viewpoints especially surprising. Ephrem praised Constantius as a faithful ruler in contrast to Julian, and Jacob praised Justin as a faithful ruler in light of his mercy towards Paul of Edessa.

Jacob's portrayal of Justin may seem more understandable than Ephrem's praise for Constantius. Justin had indeed saved Paul of Edessa from persecution, and Jacob may very well have seen this as a shift in his policy and perhaps Justin's own perspective on Christology. He would have hoped that Justin's actions at least would have changed for the betterment of the miaphysite community. Ephrem had fewer reasons to portray Constantius in a positive light. Constantius was already dead, and Ephrem would even look forward to an emperor who stood in line with Ephrem's own theological understanding. Jovian, on Ephrem's view, was a supporter of Nicaea; Constantius was not.

The responses of Ephrem and Jacob to rulers whose theology conflicted with their own grants insight into images of good Christian rulers in the late antique Syriac tradition. Neither author presents a programmatic understanding of the tasks that emperors should accomplish. They rather praise emperors for their individual actions. The contingency of these writings under situations of duress should encourage caution about the types of sources used to investigate political thought. Manolis Papoutsakis's study of Ephrem's Hymns against Julian has shown the complex eschatological and political framework within which Ephrem wrote. Yet the

110 For a brief overview of the text and scholarship on it, see Aaron M. Butts, "Julian Romance," in Gorgias Encyclopedic Dictionary of the Syriac Heritage, ed. Sebastian P. Brock et al. (Piscataway, NJ 2011), 236-238.

111 Julian Romance (Johann Georg Ernst Hoffmann, ed., Iulianos der Abtruennige: Syrische Erzaehlungen [Leiden, 1880], 5): 
historical contexts of these authors form another means of approaching their surprising positive portrayal of Constantius and Justin. They suggest that these sources feature responses to the individual actions of emperors within specific political settings.

Ephrem's and Jacob's works may thus lead to a better understanding of the effect of historical circumstances on writings on emperors in late antiquity. Constantius and Justin brought peace to Ephrem's and Jacob's communities. This peace garnered each of them praise with imagery ordinarily reserved for God and ecclesiastical leaders and through comparisons to the most honoured rulers in the Syriac Christian tradition. Both Ephrem and Jacob made comparisons to Constantine, that is, to the paradigmatic Christian ruler involved in doctrinal debates. Yet they praised Constantius and Justin not for their involvement in such debates but rather for the protection that their rule provided. The ability of an emperor to provide protection seems, in these sources, more important than an emperor's theological orthodoxy. That is the message of these texts written from the eastern border of the Roman Empire. 
